\title{
Emplacement Temperature of the Overbank and Dilute-Detached Pyroclastic Density Currents of Merapi 5 November 2010 Events using Reflectance Analysis of Associated Charcoal
}

\author{
Haryo Edi Wibowo, Anggun Purnama Edra, Agung Harijoko, and Ferian Anggara \\ Department of Geological Engineering, Faculty of Engineering, Gadjah Mada University, Yogyakarta, Indonesia
}

\begin{abstract}
Merapi eruption in 2010 produced $17 \mathrm{~km}$ high column of ash and southward pyroclastic density current (PDC). Based on the deposits characteristics and distributions, the PDC is divided into channel and overbank facies (pyroclastic flow), and associated diluted PDC (pyroclastic surge). The hot overbank PDCs and the associated dilute-detached PDCs are the main cause of high casualty (367 fatalities) in medial-distal area (5-16 km), especially near main valley of Kali Gendol. We reported the emplacement temperature of these two deposits using reflectance analysis of charcoal. We used both entombed charcoals in the overbank PDC and charcoals in singed house nearby. Samples were collected on 6-13 km distance southward from summit. Charcoalification temperatures of the entombed charcoals represent deposition temperature of the overbank PDCs, whereas those of charcoals in the singed house resembles temperature of the associated dilute-detached PDCs. Results show mean random reflectance (Ro\%) values of entombed charcoal mainly range 1.1-1.9 correspond to temperature range $328-444{ }^{\circ} \mathrm{C}$, whereas charcoal in singed house range $0.61-1.12$ with estimated temperature range $304-358{ }^{\circ} \mathrm{C}$. The new temperature data of the dilute-detached PDCs in the medial-distal area is crucial for assessing impact scenarios for exposed populations as it affects them lethally and destructively.
\end{abstract}

Keywords: Emplacement temperature · PDCs · Merapi · Reflectance analysis · Charcoal.

\section{INTRODUCTION}

Eruption of Merapi in 2010 remarked the most voluminous eruption (VEI 4) in the past 100 years activities of this volcano. Detailed chronology of this eruption is reported by Surono et al. (2012) and distribution of the southward pyroclastic density currents (PDCs) is shown in Figure 1. As reported by Surono et al. (2012), beginning of non-eruptive unrest of Merapi activity was initiated in October 31, 2009. Increasing activities since then is followed by explosive eruption in 26 and 31 October 2010. These eruptions destroy the preexisting 2006 lava dome and produce $12 \mathrm{~km}$ high ash plume, PDC moving southward to 8

\footnotetext{
${ }^{*}$ Corresponding author: H.E. WibOwO, Department of Geological Engineering, Gadjah Mada University. Jl. Grafika 2 Yogyakarta, Indonesia. E-mail: harya.edi.w@ugm.ac.id
}

$\mathrm{km}$ distance while the high energy one spread around the summit area. These activities result to enlarged and deepened summit crater which is notched towards the head drainage of Kali Gendol. Following activities in November 1-4 are remarked by rapid growth of a new lava dome in the summit area with growth rates $\sim 25 \mathrm{~m}^{3} \mathrm{~s}^{-1}$. A large eruption was recorded in November 3 producing PDCs up to $12 \mathrm{~km}$ to the south following and mainly confined in Kali Gendol channel. The activities of Merapi reached its climax in November 4 and 5 as remarked by explosive eruptions producing $17 \mathrm{~km}$ high column of ash and PDC extended $17 \mathrm{~km}$ southward. This far spread PDC reached Bronggang village $(16 \mathrm{~km})$, which unfortunately not evacuated yet, causing 367 fatalities. This eruption destroyed the newly built lava dome and enlarged the crater up to $\sim 400 \mathrm{~m}$ circular diameter which is breached to the south 
towards Kali Gendol. This post-eruption morphology of the summit area makes southern flank area vulnerable to any volcanic activities in the near future especially those around the main valley of Kali Gendol, Kali Kuning, Kali Woro, and Kali Opak.

Southward distributed PDCs generally can be grouped into pyroclastic flow and surge deposit as reported by Cronin et al. (2013), Komorowski et al. (2013), and Charbonnier et al. (2013), Trollese et al. (2018). Komorowski et al. (2013) further detailed the sub-division on the basis of deposit characteristics and their distribution into 5 types: 1) high energy PDCs, including diluted turbulent type, which are distributed near summit area; 2) Block rich confined PDC; 3) Block-poor confined PDC; 4) Block rich un-confined overbank PDC, and 5) Dilute detached un-confined PDC. Type 2, 3, and 4 can be considered as pyroclastic flow deposit thus can be simplified as channel and overbank facies PDCs. Type 1 and 5 can be considered as pyroclastic surge (Charbonnier et al., 2013). The unconfined PDCs mainly come from erupted materials of 3-5 November events. They are mainly caused by reduced capacity as it was filled by earlier confined PDCs and narrowing valley morphology in the middle part of Kali Gendol (Komorowski et al., 2013). The avulsed pyroclastic materials flowed crossing over transverse topographic ridges up to $245 \mathrm{~m}$ high in the paroxysmal area and up to tens of meters in the medial area. Consequently, this overbank facies PDC widen the impact of this event to the populated area near the down slope of Gendol valley. In addition to that, associated dilute-detached deposits further widen the invaded area especially on the medial-distal zone $(5-16 \mathrm{~km})$. These two types of unconfined PDCs become the main cause of the high casualties in medial-distal zone (Baxter et al., 2017).

PDCs of Merapi 2010 are hot and destructive as evidenced by singed trees near the proximal area and the burned house near the main channel. In addition, vegetation and plant entombed in the PDCs are fully charred as reported by Cronin et al. (2013), Komorowski et al. (2013), Charbonnier et al. (2013), and Trolese et al. (2018). However, there was no report of burning flames on the PDCs singed zone during the climactic eruption events (Jenk- ins et al., 2013). Thus charcoal materials related to the PDCs impact might represent its temperature dynamic. Reflectance analysis of the charcoal to estimate deposition temperature of pyroclastic materials has been widely used, e.g. Soufrière Hills (Scott and Glasspool, 2005; Scott et al., 2008), Taupo (Hudspith et al., 2010), Vesuvius (Caricchi et al., 2014), Colima (Pensa et al., 2018), Fogo (Pensa et al., 2015), Sundoro (Harijoko et al., 2018), and Merapi (Trolese et al., 2018). The latest mentioned reported deposition temperature of both channel and overbank facies PDCs erupted in 2010. The study covers both deposits extended from 2 to $15 \mathrm{~km}$ distance from the summit. The reported temperature range $240-320^{\circ} \mathrm{C}$ and shows no correlation to distance from the summit and no significant difference between channel and overbank facies. It suggests for very rapid cooling of the pyroclastic materials since the initiation of the collapse of dome material (approximate temperature $\sim 600{ }^{\circ} \mathrm{C}$ ) to the closest reported point $\sim 2 \mathrm{~km}$ (temperature range $240-320{ }^{\circ} \mathrm{C}$ ). In addition, the highly fast moving pyroclastic flow might took important place in "keeping" the high temperature. In this research, we reported new temperature data of the dilutedetached PDC in the medial-distal area. We included new data of emplacement temperature of the overbank facies pyroclastic flow deposit as comparison. Both deposits are related to 5 November events. Detailed research of thermal state of PDCs will provide crucial view to the flow dynamics, and increases our ability to assess and mitigate the potential hazards in the future.

\section{Materials And Analytical Method}

\subsection{Deposit of pyroclastic density current}

Field observations were conducted in three separated locations span from 6 to $13 \mathrm{~km}$ distance from the summit. All of the observation points are located in the medial-distal area which only exposed to 3-5 November events (Figure 1). Bakalan village (13 km distance from summit) is one of the populated area impacted by overbank and associated dilute-detached PDCs. Detailed observation of satellite image, taken on 11 November 2010, by Charbonnier et al. (2013) suggested that some part of this village was totally buried by overbank PDCs whereas the 


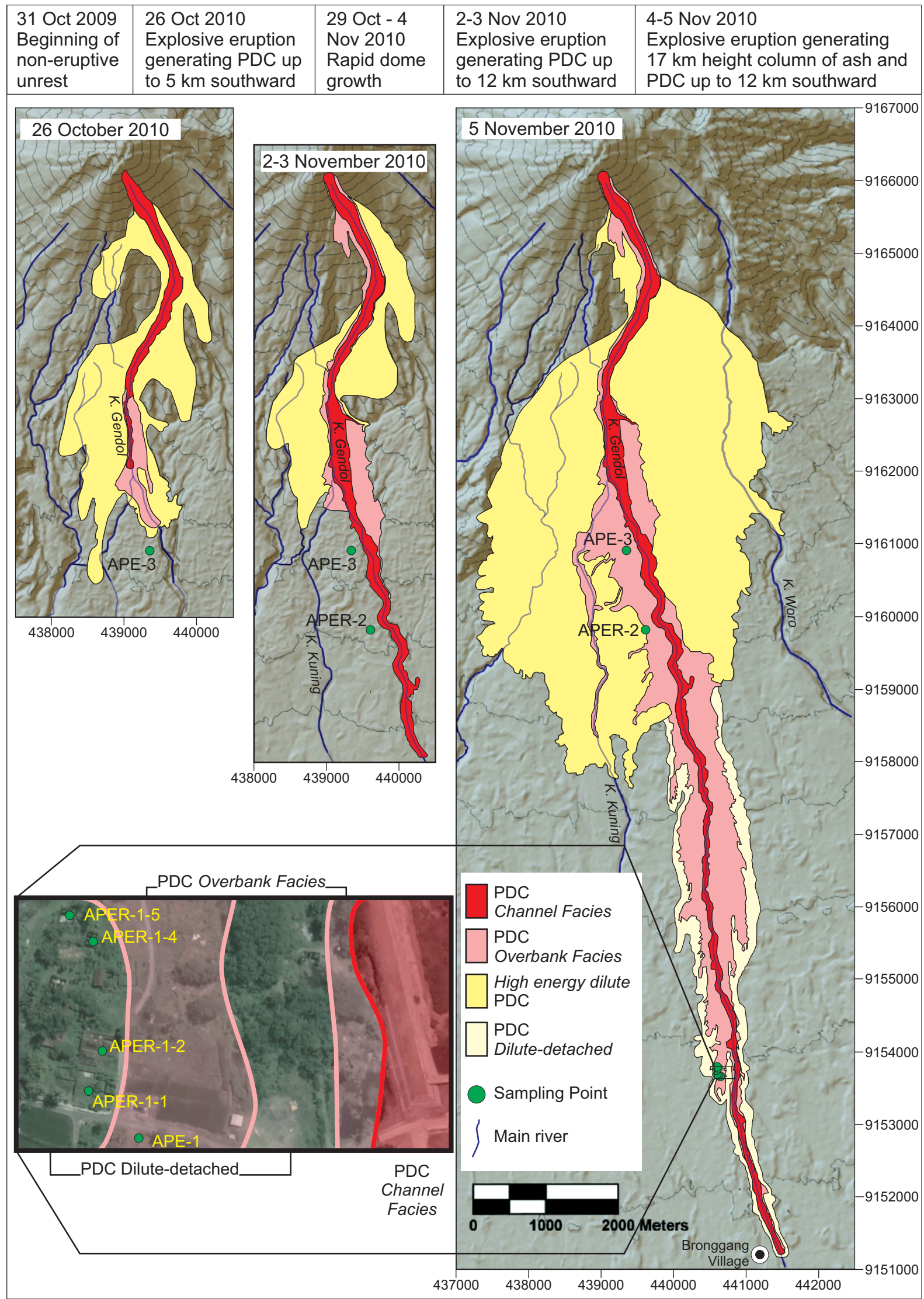

Figure 1. Brief chronology of Merapi activities since the initial non-magmatic unrest up to the climactic magmatic eruption in November 5, 2010. Spatial distribution of the PDCs refers to Cronin et al. (2013). Indexed map shows the location of Bakalan village one of the most damaged area in medial-distal region. Observations points are shown in solid green circle. 
nearby standing singed houses was covered by fine ash deposits.

Our observation point on overbank PDCs in Bakalan village (APE-1) shows a single layer deposit, $\sim 2 \mathrm{~m}$ thick, and structurally massive. It composed of very loose, poorly sorted, juvenile of dense vitric andesite. Fragments of 0.3 to $1 \mathrm{~m}$ sizes entombed in fine-coarse ash matrix. This deposit contains charred vegetations such as coconut trunks, bamboo, and shredded wooden house (Figure 2). Another outcrop of the overbank PDCs was observed in $6 \mathrm{~km}$ distance from summit (APE-3). It is $\sim 1 \mathrm{~m}$ thick and shows similar characteristics of block-rich and containing charred vegetation. The overbank deposit in APE-3 is rested on top of high energy PDCs deposit. This preceding deposit is $\sim 5 \mathrm{~cm}$ thick, reddish in color, fine ash dominated, and contains lithic of gravel size dense andesite. These characteristics are similar to the high energy dilute PDCs (ground surge) reported by Charbonnier et al. (2013), Komorowski et al. (2013), and Cronin et al. (2013). This dilute PDCs deposit rested on top of old soil or preexisted asphalt road. In some places, this deposit is scoured by the overlying overbanks deposit.

\subsection{Charcoal}

We collected samples of entombed charcoal from the overbank PDCs which are produced from coconut tree and materials likely related to housing construction such as bamboo and wood as shown in Figure 2. Nine samples of charcoal were collected from APE-01 and one from APE-03. Most of them are fully charred including a sample from exterior part of a standing still coconut tree. However the inner part of this tree (APE 01-02A) was not fully charred.

Charcoal samples representing dilute detached PDCs are collected from the ruin of partially destroyed houses of Bakalan village, about $200 \mathrm{~m}$ from the main Gendol valley. We collected four charcoal samples each representing different houses near APER-01 and one sample from APER-02. Ruined houses in APER-01 and APER-02 are $200 \mathrm{~m}$ cross distance from main channel of Kali Gendol, and $10 \mathrm{~m}$ from boundary of overbank PDCs as suggested by Cronnin et al. (2013). These charcoal samples are derived from wooden sills. Charcoalification occurred on the surface of the sills up to $1-3 \mathrm{~mm}$ towards inner part (Figure 3 ). This method cannot entirely exclude the possibility of burning flame generated from flammable utensils such as explosions of flammable materials e.g. butane/propane gas as commonly used gas for cooking and the petrol stored in motorbikes or plastic tank which is quite common for local people. However, we carefully selected the uniformly charred wooden sills as it may resemble typical charcoalification in the low oxygen and high temperature environment. Distributions of the analyzed samples are presented in Figure 3. Details of the charcoal samples in this study are shown in Table 1.

\subsection{Reflectance analysis}

Samples were cleaned using soft plastic brush to remove pyroclastic materials and avoid contamination. The big size samples, especially the entombed charcoal, were cut approximately $2 \mathrm{~cm}$ size cube to collect the interior part. All charcoal samples then were crushed and sieved to obtain $\sim 1 \mathrm{~mm}$ size materials. Samples then bathed in epoxy resin for wet polished section preparation. During preparation, samples were kept in room temperature and not heated to prevent any possible effect to the organic materials. Polishing the samples were done using SIC grit paper 500 and 1200, followed by polishing cloth and diamond suspension lubricant, then finished with polishing cloth and colloidal silica lubricant. Compositions of the polished charcoal were determined following ASTM D2799-05a (2005) which have been modified for charcoal observation. These preparations were conducted in Central Laboratory, Geological Engineering Department, Faculty of Engineering, Universitas Gadjah Mada.

Reflectance measurements were conducted under a CRAIC image analysis system connected to a CRAIC polarizing microscope. This step was done at $546 \mathrm{~nm}$ under oil of refractive index 1.518 following Australian Standard AS 2856-1986 (1986). Measurements include 30 points traverse across the sample to get the mean maximum reflectance number $\left(R_{\max }\right)$ of each sample. These reflectance measurements were performed in the commercial TekMIRA coal laboratory in Bandung, Indonesia. 

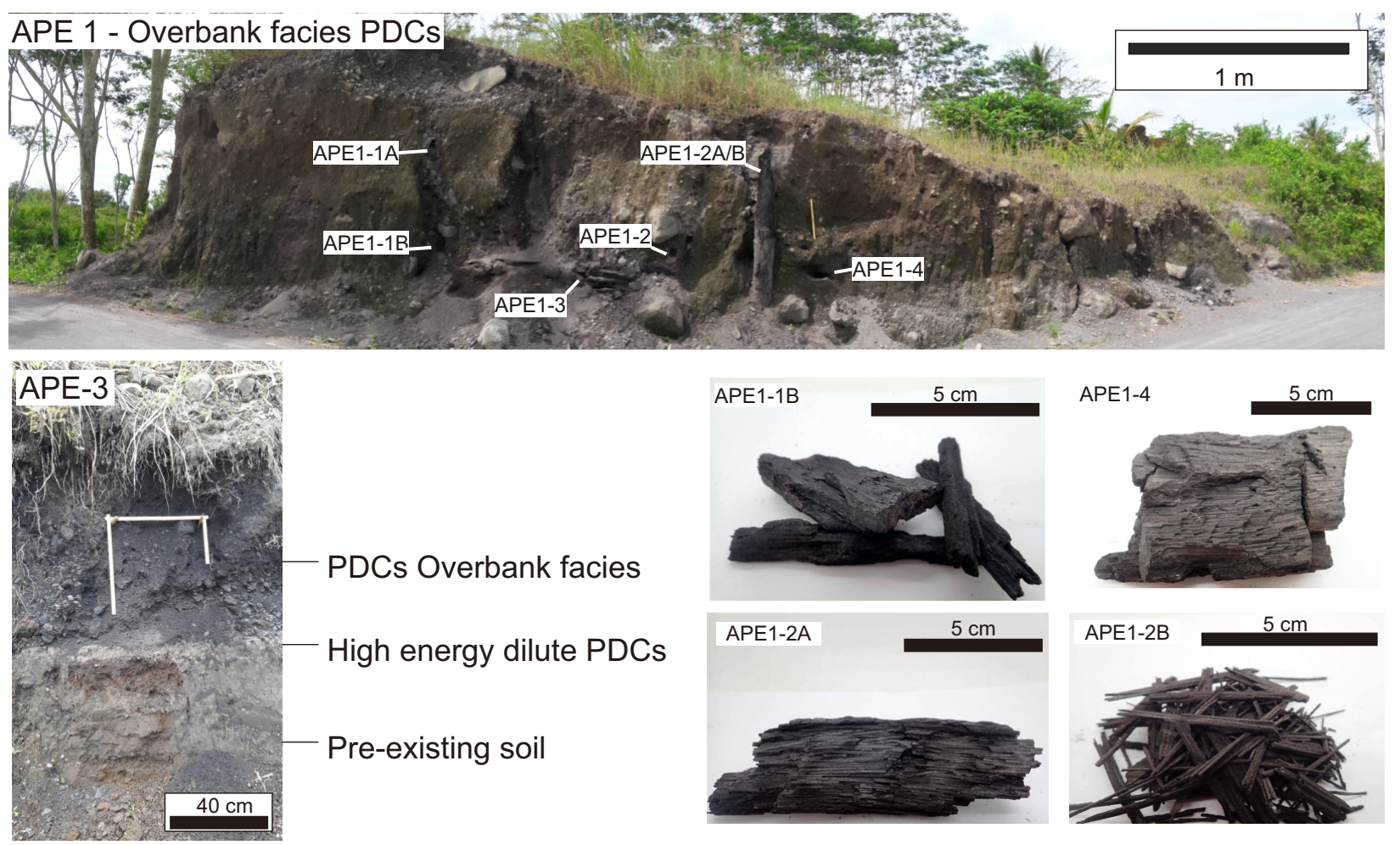

Figure 2. Outcrop of the overbank deposits in Bakalan village (APE-1) about $13 \mathrm{~km}$ distance from the summit and APE-3 overbank PDCs deposits $6 \mathrm{~km}$ distance. Entombed charcoals of the overbank deposits mostly are fully charred except the inner part of standing still coconut tree (APE-1-2B).

Table 1. Type and locality of the analyzed charcoal samples.

\begin{tabular}{|c|c|c|c|c|c|}
\hline \multirow{2}{*}{ No } & \multirow{2}{*}{ Sample } & \multirow{2}{*}{ Type } & \multicolumn{2}{|c|}{ Coordinate (UTM 49M) } & \multirow{2}{*}{ Notes } \\
\hline & & & North & East & \\
\hline 1 & APE-01-01A & Coconut trunk & \multirow{8}{*}{9153656} & \multirow{5}{*}{440635} & \multirow{8}{*}{$\begin{array}{l}\text { Entombed charcoal in } \\
\text { overbank facies PDCs }\end{array}$} \\
\hline 2 & APE-01-01B & Coconut trunk & & & \\
\hline 3 & APE-01-01C & Coconut trunk & & & \\
\hline 4 & APE-01-02A & $\begin{array}{l}\text { Inner part of } \\
\text { standing still } \\
\text { Coconut trunk }\end{array}$ & & & \\
\hline 5 & APE-01-02B & $\begin{array}{l}\text { Outer part of } \\
\text { standing still } \\
\text { Coconut trunk }\end{array}$ & & & \\
\hline 6 & APE-01-03 & Bamboo beam & & & \\
\hline 7 & APE-01-04A & Coconut trunk & & & \\
\hline 8 & APE-01-04B & Coconut trunk & & & \\
\hline 10 & APER-02 & Wood beam & 9159813 & 439604 & $\begin{array}{l}\text { Charred wood sills of the } \\
\text { houses ruin }\end{array}$ \\
\hline 11 & APE-03 & Tree trunk & 9160906 & 439339 & $\begin{array}{l}\text { Entombed charcoal in } \\
\text { overbank facies PDCs }\end{array}$ \\
\hline 12 & APER-01-01 & Wood beam & 9153676 & 440605 & $\begin{array}{l}\text { Charred wood sills of the } \\
\text { houses ruin }\end{array}$ \\
\hline 13 & APER-01-02 & Wood beam & 9153704 & 440608 & \multirow{3}{*}{$\begin{array}{l}\text { Charred wood sills of the } \\
\text { houses ruin }\end{array}$} \\
\hline 14 & APER-01-04 & Wood beam & 9153774 & 440605 & \\
\hline 15 & APER-01-05 & Wood beam & 9153788 & 440592 & \\
\hline
\end{tabular}




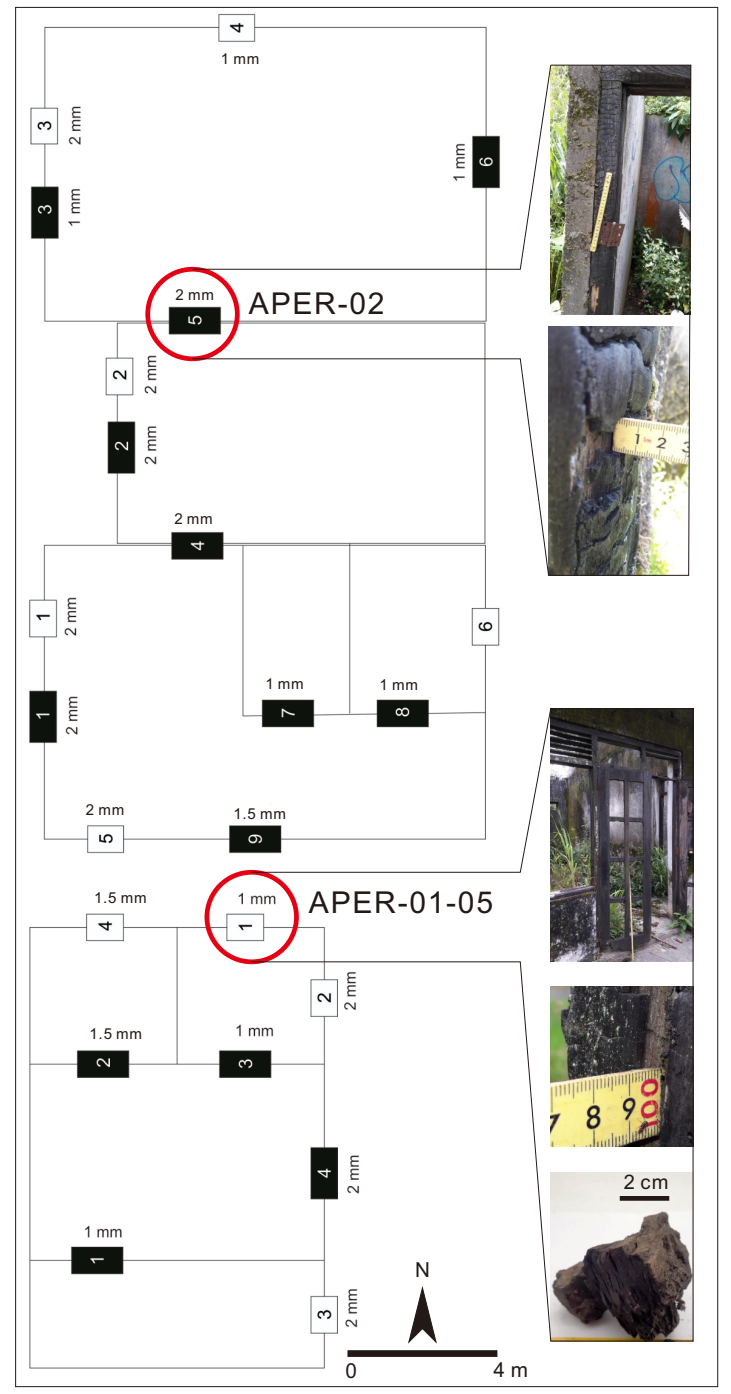

Figure 3. Thickness distributions of the charred wooden sills of the ruined houses exposed to dilutedetached PDCs. Solid black squares resemble door sills, white squares resembles window sills.

\section{RESUlts AND Discussion}

\subsection{Characteristics of PDC deposits}

Detailed grain size characteristics of the overbank PDCs deposits was obtained by conducting grain size distribution analysis using sieve mesh phi $(\phi)-4-4$. The result then plotted within grain-size distribution diagram for pyroclastic deposits from Walker (1971). Samples from the overbank PDCs deposits mostly plotted within the pyroclastic flow field (Figure 4). Overall, the overbank PDCs deposits are coarse grained and poorly sorted $(\mathrm{Md} \phi-1.5$ to $0.5 ; \sigma \phi$ 3.45 to 3.62). They are plotted within range of previously reported number $\operatorname{Md} \phi-5.58$ to 0.21 and $\sigma \phi 2.19$ to 4.07 by Charbonnier et al. (2013), and $\operatorname{Md} \phi-4$ to 3.8 and $\sigma \phi 1$ to 4 by Komorowski et al. (2013). Both reports highlighted that both overbank and channeled facies PDCs deposits have similar grain size characteristics and implying that processes of overbanking directly related to the main body of channeled PDCs.

Deposits of the dilute-detached PDCs were not found during our field campaign in March 2018. The deposits may have been washed out by intense rain in Merapi region considering their characteristics. Charbonnier et al. (2013) reported the distribution of the deposits in the medial-distal area is up to $75 \mathrm{~m}$ lateral from the main valley. The deposit is a few centimeters thick possessing characteristics of loose fine grained ash and relatively well sorted $(\mathrm{Md} \phi 2$ to $4 ; \sigma \phi 1$ to 2 ) as shown in Figure 4.

\subsection{Temperatures}

In general, most of the collected materials had a black color, lustrous luster, and gives a black streak on papers and hands. Under reflected light microscope, homogenized cell wall of the charred materials is clearly visible (Figure 5). Thus, according to Scott (2010), all of the samples collected could be categorized as charcoal.

Results of the optical reflectance analysis are presented in Table 2. Prior to temperature estimation, the obtained mean maximum reflectance $\left(R_{\max }\right)$ number need to be converted to mean random reflectance number $\left(R_{0} \%\right)$ through equation $R_{\max }=1,090 \times R_{0} \%-$ 0.052 suggested by Komorek and Morga (2002). Charcoalification temperature was then estimated by plotting mean random reflectance $\left(R_{0} \%\right)$ to temperature curves reported by Jones et al. (1991), Scott and Glasspool (2005; 2007), and Ascough et al. (2010). These four $R_{0^{-}}$ Temperature curves are shown in Figure 6. As a result, each $R_{0} \%$ number yields four different estimated temperature numbers. These four different results were then averaged to obtain the mean temperature in which was then used as the most probable charcoalification temperature for each sample as listed in Table 2.

Generally, charcoal fragments were wellpreserved within the 5 November overbank PDC deposits. $R_{0} \%$ number of these charcoals range from 0.63 to 1.9 thus gives temperature range $306-444{ }^{\circ} \mathrm{C}$. Lowest temperature, $306^{\circ} \mathrm{C}$ related to $R_{0} \% 0.63$, comes from inner part of the standing still coconut tree (APE-01-02A). This temperature is lower than that of the outer 


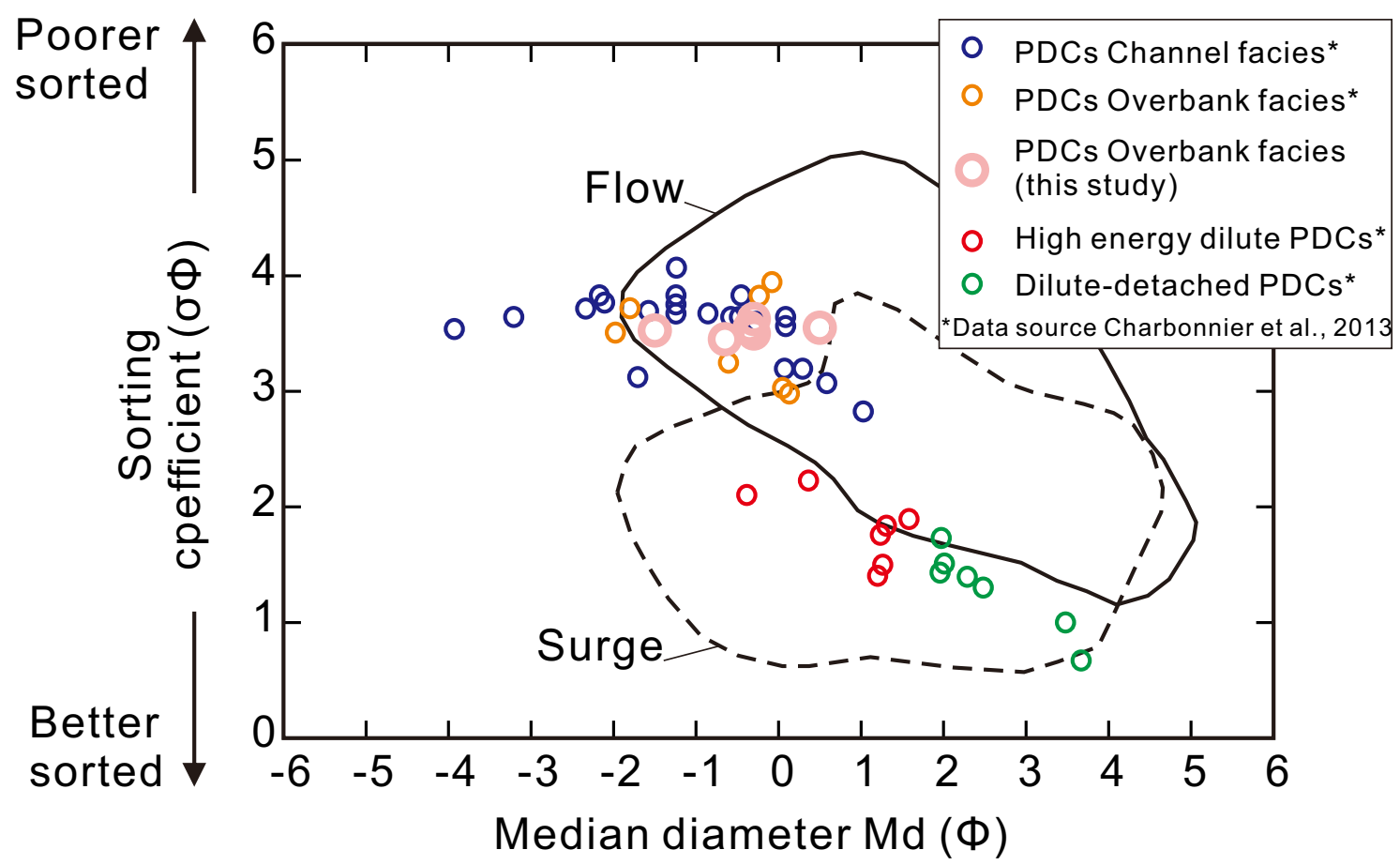

Figure 4. Plot of median diameter $(\mathrm{Md} \phi)$ versus sorting coefficient $(\sigma \phi)$ for overbank PDCs deposit in this study. Data including both channel and overbank dense PDCs, and dilute PDCs from Charbonnier et al. (2013) are plotted as comparison. Boundaries of pyroclastic flow and surge deposits refer to Walker (1971).

Table 2. Optical reflectance data and related temperature estimation for each sample.

\begin{tabular}{cccccccc}
\hline No & Sample & $\begin{array}{c}\text { Max. } \\
\text { Reflec- } \\
\text { tance } \\
(\%)\end{array}$ & $\begin{array}{c}\text { Min. } \\
\text { Reflec- } \\
\text { tance } \\
(\%)\end{array}$ & $\begin{array}{c}\text { Mean Max. } \\
\text { Reflec- } \\
\text { tance } \\
\left(R_{\text {max }} \%\right)\end{array}$ & $\begin{array}{c}\text { Std. dev. } \\
(\%)\end{array}$ & $\begin{array}{c}\text { Mean } \\
\text { Random } \\
\text { Reflec- } \\
\text { tance }\left(R_{o},\right. \\
\%)\end{array}$ & $\begin{array}{c}\text { Avg. Temp. } \\
\left({ }^{\circ} \mathrm{C}\right)\end{array}$ \\
\hline 1 & APE-01-01A & 2 & 1.88 & 1.93 & 0.03 & 1.62 & $422 \pm 46$ \\
2 & APE-01-01B & 1.36 & 1.25 & 1.3 & 0.03 & 1.2 & $381 \pm 22$ \\
3 & APE-01-01C & 2.45 & 2.35 & 2.4 & 0.03 & 1.9 & $444 \pm 40$ \\
4 & APE-01-02A & 0.7 & 0.61 & 0.67 & 0.02 & 0.63 & $306 \pm 54$ \\
5 & APE-01-02B & 0.96 & 0.92 & 0.93 & 0.01 & 0.85 & $328 \pm 48$ \\
6 & APE-01-03 & 1.3 & 1.2 & 1.26 & 0.03 & 1.25 & $376 \pm 43$ \\
7 & APE-01-04A & 1.29 & 1.2 & 1.25 & 0.03 & 1.15 & $362 \pm 43$ \\
8 & APE-01-04B & 1.76 & 1.65 & 1.71 & 0.04 & 1.65 & $426 \pm 44$ \\
10 & APER-02 & 1.16 & 1.06 & 1.1 & 0.03 & 0.9 & $333 \pm 47$ \\
11 & APE-03 & 1.68 & 1.55 & 1.6 & 0.03 & 1.42 & $402 \pm 50$ \\
12 & APER-01-01 & 0.61 & 0.55 & 0.58 & 0.02 & 0.61 & $304 \pm 55$ \\
13 & APER-01-02 & 1.32 & 1.17 & 1.24 & 0.04 & 1.12 & $358 \pm 43$ \\
14 & APER-01-04 & 0.8 & 0.7 & 0.75 & 0.03 & 0.65 & $308 \pm 54$ \\
15 & APER-01-05 & 0.96 & 0.85 & 0.91 & 0.03 & 0.71 & $314 \pm 52$ \\
\hline
\end{tabular}



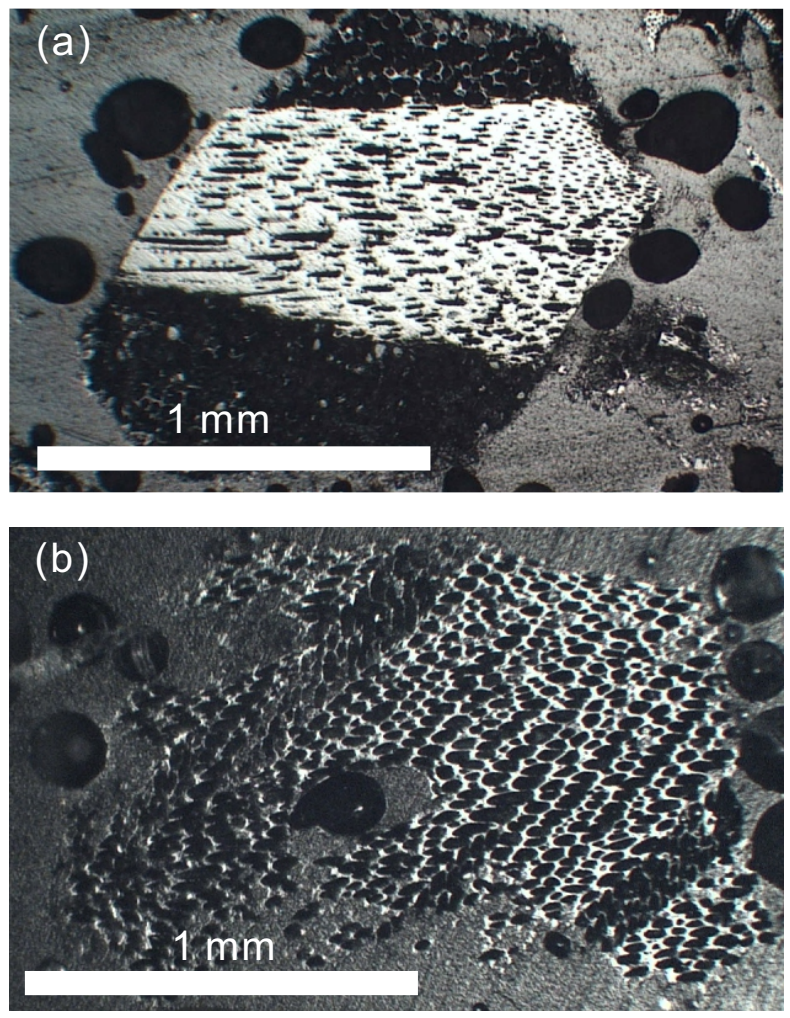

Figure 5. Photomicrographs of polished charcoal showing homogenized cell walls resembling fully charred fragments from (a) entombed charcoal APE1-3 $\left(R_{o} \% 1.9\right)$ and charred wooden sills of burned house APER-1-2 ( $\left.R_{o} \% 1.12\right)$.

part (APE-01-02B) $328^{\circ} \mathrm{C}$. Sawada et al. (2000) suggested that charcoalification temperature in a body of charred vegetation may be different from parts to parts due to different cooling rates. It is likely that the difference of inner and outer part of this standing coconut tree might correspond to the partial charcoalification of the inner part. Consequently, we excluded this sample from further discussion as it might not represent the actual temperature of the overbank PDCs deposit. Thus we suggested that the estimated temperature of the overbank PDCs range $328-444^{\circ} \mathrm{C}$.

Temperature of PDC deposits generated by dome collapse is complicated to assess. This is mainly due to the fact that the extent of cooling of the lava dome prior to collapse is unknown. Generally, temperatures of domecollapsed PDCs deposits may vary significantly due to the large thermal range of the dome as the source materials (Uehara et al., 2015). Estimated emplacement temperature of Merapi dome-collapsed PDCs from previous study yields broad range. Voight and Davis (2000) reported temperature of $550{ }^{\circ} \mathrm{C}$ for 1994 channelized block-and-ash-flow deposit which was estimated from burned plastic materials. Charbonnier and Gertisser (2008) estimated temperature of block-and-ash-flow deposit erupted in 2006 is $\sim 400{ }^{\circ} \mathrm{C}$. Using charcoal reflectance analysis, Trolese et al. (2018) estimated the emplacement temperature of both channel and overbank facies PDCs of Merapi 2010 range $240-320{ }^{\circ} \mathrm{C}$. This result is slightly lower than that estimated temperatures of this study. High temperature of $420-660{ }^{\circ} \mathrm{C}$ in block-and-ash flow deposit might correspond to thermal disequilibrium as bigger clasts might hotter than surrounding ash matrix (Sawada et al., 2000; Harijoko et al., 2018; Trolese et al., 2018). Grain size characteristics of the overbank deposits in this study are within range of the previously reported data (Charbonnier et al., 2013; Komorowski et al., 2013). In addition, our result is within range of those previously mentioned older activities of 1994 and 2006. Trolese et al. (2018) suggested that high temperature of the PDC deposits produced during the 5 November 2010 events might related to several factors; 1) the high lava dome growth rate during 1-4 November $\left(\sim 25 \mathrm{~m}^{2} \mathrm{~s}^{-1}\right.$; Pallister et al., 2013) indicating that most of the lava dome that collapsed on 5 November was composed of mostly fresh and hot magmas. 2) Crystal growth analysis suggested that the temperature of this lava dome is estimated to range $925-1000{ }^{\circ} \mathrm{C}$ (Preece et al., 2016). 3) The considerable amount of dense juvenile material in the PDCs, as reported by Komorowski et al. (2013), might keep the heat of the deposits.

Dilute-detached PDCs were distributed up to $75 \mathrm{~m}$ around the associated overbank PDCs and singed either the surrounding vegetation or the exposed-houses (Charbonnier et al., 2013). Our observation shows that wooden sills of the singed houses are charred up to 1 to $3 \mathrm{~mm}$ thickness on the surface. Figure 3 shows that thicknesses of the charcoalification are mostly random and show no correlation to relative distance to the main channel of Kali Gendol. In addition, eastern sides of the ruined houses, as the most likely side which directly impacted by PDCs, are not systematically thicker than other sides. 


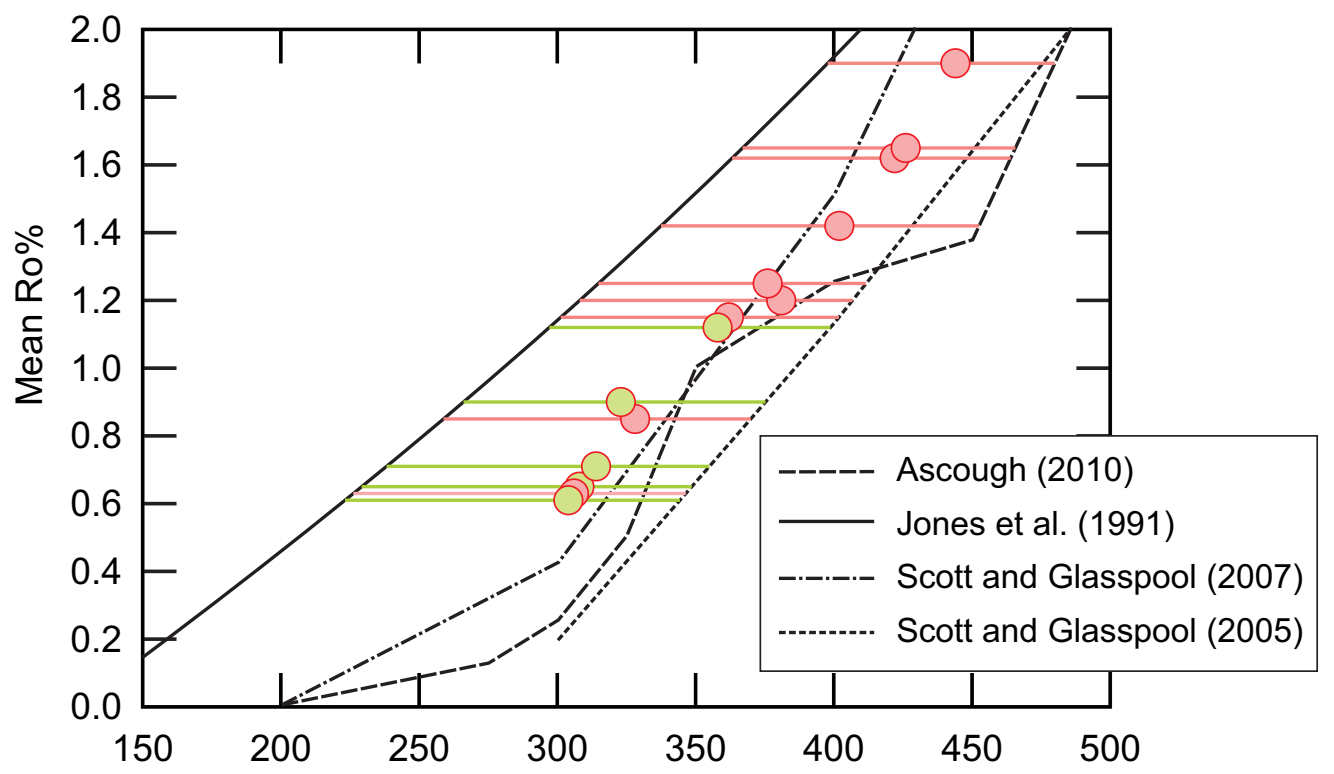

Figure 6. Estimation of paleo-temperature using $R_{0} \%$ value plotted against experimental curves after Jones et al. (1991), Scott and Glasspool (2005; 2007), and Ascough (2010). Range temperatures obtained from each curves (pink and green lines) were then averaged. The result were then taken as the representative paleotemperature of overbank PDCs deposits (solid pink circle) and dilute-detached PDCs (solid green circle).

$R_{0} \%$ number of these charred wooden sills range from 0.61 to 1.12 and yields estimated temperatures of the dilute-detached PDCs range from 304 to $358{ }^{\circ} \mathrm{C}$. Generally, this result is within range to those previously suggested temperatures estimated using various approaches such as melting plastic pots $\left(>170{ }^{\circ} \mathrm{C}\right.$ : Voight and Davis, 2000) and singed acrylic and nylon clothing $\left(<400{ }^{\circ} \mathrm{C}\right.$ : TNO, 1992) but slightly higher than those estimated temperature considering the burning injuries occurred on the dead body in the Bronggang village ( $15 \mathrm{~km}$ distance from the summit) range 200-300 ${ }^{\circ} \mathrm{C}$ (Jenkins et al., 2013).

Structure of the cell wall of a wood can be homogenized by charcoalification involving temperature higher than $300{ }^{\circ} \mathrm{C}$ but will be less homogenized in temperature beneath (Scott, 2000). The charcoal samples analyzed in this study show relatively homogenized cell wall structure (Figure 5). Thus it is expected that estimated temperature in this study may exceed $300{ }^{\circ} \mathrm{C}$. Overall, estimated results range $304-444{ }^{\circ} \mathrm{C}$ is in accordance with cell wall homogenization temperatures suggested from the literature.

Temperature difference between the overbank PDCs $\left(328-444^{\circ} \mathrm{C}\right)$ and associated dilutedetached PDCs $\left(304-358^{\circ} \mathrm{C}\right.$ ) remarked temperature down in the PDCs dynamics particularly in the medial-distal area. Temperature down between this dense and the associated diluted PDCs might correspond to efficient ingestion of air with atmospheric temperature to the main body of the flow. This ingestion might increase the volume of the expanding ash cloud and generates cooler and diluted PDCs as illustrated in Figure 7. Similar pattern was reported in Merapi 1994 (Voight and Davis, 2000) where dense PDCs were deposited at a temperature about $550{ }^{\circ} \mathrm{C}$, while detached dilute deposit were below $200{ }^{\circ} \mathrm{C}$. Similarly, the 2006 PDCs main deposit were emplaced at $400{ }^{\circ} \mathrm{C}$ while the diluted PDCs at $165{ }^{\circ} \mathrm{C}$ as reported by Charbonnier and Gertisser (2008). This high temperature cloud can be highly lethal and destructive to the exposed population.

\section{CONCLUSION}

We have reported reflectance data of charcoal associated to overbank and dilute-detached PDCs during the 5 November 2010 event. Reflectance data $\left(R_{0} \%\right)$ range from 1.1 to 1.9 for those related to overbank PDCs and 0.61 to 1.12 for those correspond to dilute-detached PDCs. The results means emplacement temperature of overbank PDCs $\left(328-444{ }^{\circ} \mathrm{C}\right)$ is higher than the associated dilute-detached PDCs $\left(304-358{ }^{\circ} \mathrm{C}\right)$. These temperature data are randomly distributed within 6 to $13 \mathrm{~km}$ 


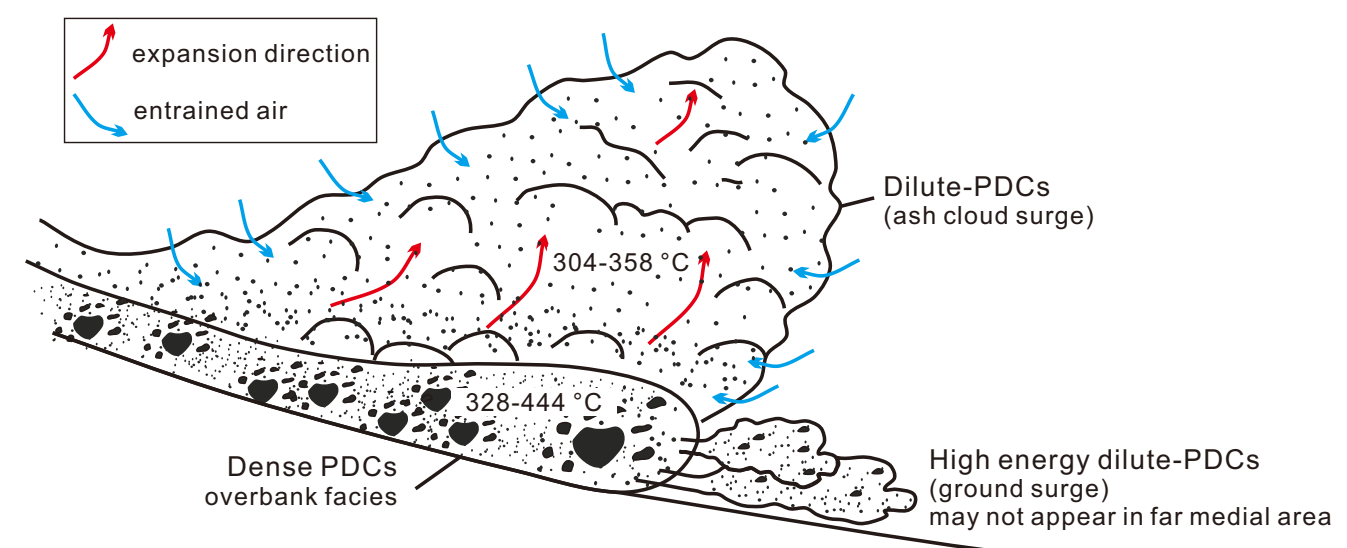

Figure 7. Illustration of the air ingestion to the main body of the flow potentially causes temperature down of hot overbank PDCs towards "cooler" dilute-detached PDCs.

distance from the summit indicating that thermal energy was not correlated to emplacement distance. Efficient ingestion of surrounding air with atmospheric temperature to the main body of the flow might increase the volume of the expanding ash cloud and generates cooler and diluted PDCs. Despite of the relatively diluted characteristics, the temperature ranges of dilute-detached PDCs is lethal for exposed population and might caused significant damage to the buildings. This result has considerably implication to the assessment of the thermal risk resulted by PDCs to people and infrastructures, especially, in medial-distal area.

\section{ACKNOWLEDGEMENTS}

This research is fully funded by Internal Research Grant from Geological Engineering, Faculty of Engineering, Universitas Gadjah Mada with contract number 382/H1.17TGL/PL/2018.

\section{REFERENCES}

Ascough, P.L., Bird, M.I., Scott, A.C., Collinson, M.E., Cohen-Ofri, I., Snape, C.E., Le Manquais, K. (2010) Charcoal reflectance measurements: implications for structural characterization and assessment of diagenetic alteration. Journal Archaeological Science 37: 1590-1599. DOI: https://doi.org/10.1016/j.jas.2010.01.020.

ASTM D2799-05a (2005) Standard Test Method for Microscopical Determination of the Maceral Composition of Coal.

Baxter, P.J., Jenkins, S., Rosadi, S., Komorowski, J.-C., Dunn, K., Purser, D., Voight, B., Shelley, I. (2017). Human survival in volcanic eruptions: thermal injuries in pyroclastic surges, their causes, prognosis and emergency management. Burns DOI: https:/ /doi.org/10.1016/j.burns.2017.01.025.

Bronto, S., Sayudi, D. S., Muzani, M., Putra, R. (2011) Potential Hazard of Merapi in The Near Future. International Workshop Lesson Learned from the 2010 Merapi Eruption, November 01-02 2011. Yogyakarta.

Caricchi, C., Vona, A., Corrado, S., Giordano, G., Romano, C. (2014) 79AD Vesuvius PDC deposits' temperatures inferred from optical analysis on woods charred in-situ in the Villa dei Papiri at Herculaneum (Italy). Journal of Volcanology and Geothermal Research 289: 14-25.

Charbonnier, S.J., Gertisser, R. (2008) Field observations and surface characteristics of pristine blockand-ash flow deposits from the 2006 eruption of Merapi volcano, Java, Indonesia. Journal of Volcanology and Geothermal Research 177: 971-982.

Charbonnier, S.J., Germa, A.M., Connor, C.B., Gertisser, R., Preece, K., Komorowski, J.-C., Lavigne, F., Dixon, T.H., Connor, L.J. (2013) Evaluation of the impact of the 2010 pyroclastic density currents at Merapi volcano from high-resolution satellite imagery, field investigations and numerical simulations. Journal of Volcanology and Geothermal Research 261: 295-315.

Cronin, S.J., Lube, G., Dayudi, D.S., Sumarti, S., Subrandiyo, S., Surono (2013) Insights into the October-November 2010 Gunung Merapi eruption (Central Java, Indonesia) from the stratigraphy, volume and characteristics of its pyroclastic deposits. Journal of Volcanology and Geothermal Research 261: 244-259.

Harijoko, A., Mariska, N.A.S., dan Anggara, F. (2018) Estimated Emplacement Temperatures for a Pyroclastic Deposits from the Sundoro Volcano, Indonesia, using Charcoal Reflectance Analyses. Indonesian Journal on Geoscience 5(1): 1-11.

Hudspith, V.A., Scott, A.C., Wilson, C.J.N., Collinson,M.E. (2010) Charring of woods by volcanic processes: an example from the Taupo 
ignimbrite, New Zealand. Palaeogeography Palaeoclimatology Palaeoecology 291: 40-51.

Jenkins, S., Komorowski, J.-C., Baxter, P.J., Spence, R., Picquot, A., Lavigne, F., dan Surono (2013) The Merapi 2010 Eruption : An Interdisciplinary Impact Assessment Methodology for Studying Pyroclastic Density Current Dynamic. Journal of Volcanology and Geothermal Research 261: 316-329.

Jones, T.P., Scott, A.C., dan Cope, M. (1991) Reflectance measurements and the temperature of formation of modern charcoals and implications for studies of fusain. Bulletin de la Societe Geologique de France 162: 193-200.

Jousset, P., Pallister, J., dan Surono. (2013) The 2010 Eruption of Merapi Volcano. Journal of Volcanology and Geothermal Research 261: 1-6.

Komorek, J. dan Morga, R. (2002) Relationship between the maximum and the random reflectance of vitrinite for coal from the Upper Silesian Coal Basin. Fuel 81: 969-971.

Komorowski, J.-C., Jenkins, S., Baxter, P.J., Picquout, A., Lavigne, F., Charbonnier, S., Gertisser, R., Preece, K., Cholik, N., Budi-Santoso, A., Surono (2013) Paroxysmal dome explosion during the Merapi 2010 eruption: processes and facies relationships of associated high-energy pyroclastic density currents. Journal of Volcanology and Geothermal Research 261: 260-294.

Pallister, J.S., Schneider, D.J., Griswold, J.P., Keeler, R.H., Burton, W.C., Noyles, C., Newhall, C.G., Ratdomopurbo, A. (2013). Merapi 2010 eruption-chronology and extrusion rates monitored with satellite radar and used in eruption forecasting. Journal of Volcanology and Geothermal Research 261: 144-152.

Pensa, A., Porreca, M., Corrado, S., Giordano, G., Cas, R. (2015) Calibrating the pTRM and charcoal reflectance $\left(R_{0} \%\right)$ methods to determine the emplacement temperature of ignimbrites: Fogo A sequence, São Miguel, Azores, Portugal, as a case study. Bulletin of Volcanology 77 (18).

Pensa, A., Capra, L., Giordano, G., Corrado, S. (2018) Emplacement temperature estimation of the 2015 dome collapse of Volcán de Colima as key proxy for flow dynamics of confined and unconfined pyroclastic density currents. Journal of Volcanology and Geothermal Research 357: 321-338.

Preece, K., Gertisser, R., Barclay, J., Charbonnier, S.J., Komorowski, J.-C., Herd, R.A. (2016) Transitions between explosive and effusive phases during the cataclysmic 2010 eruption of Merapi volcano, Java, Indonesia. Bulletin Volcanology 78 (54).
Sawada, Y., Sampei, Y., Hyodo, M., Yagami, T., Fukue, M. (2000) Estimation of emplacement temperature of pyroclastic flows using $\mathrm{H} / \mathrm{C}$ ratios of carbonized wood. Journal of Volcanology and Geothermal Research 104: 1-20.

Scott, A.C. (2000) The Pre-Quaternary history of fire. Journal of Palaeogeography, Palaeoclimatology, Palaeoecology, 164 (1-4): 281-329. DOI: https://doi.org/10.1016/S0031-0182(00)00192-9.

Scott, A.C. and Glasspool, I.J. (2005) Charcoal reflectance as a proxy for the emplacement temperature of pyroclastic flow deposits. Geology 33: 589-592.

Scott, A.C., Sparks, R.S.J., Bull, I.D., Knicker, H., Evershed, R.P. (2008) Temperature proxy data and their significance for the understanding of pyroclastic density currents. Geology 36: 143-146.

Scott, A.C. (2010) Charcoal recognition, taphonomy and uses in palaeoenvironmental analysis. Palaeogeography Palaeoclimatology Palaeoecology 291: 11-39.

Surono, Jousset, P., Pallister, J., Boichu, M., Buongiorno, M.F., Budisantoso, A., Costa, F., Andreastuti, S., Prata, F., Schneider, D., Lieven, C., Humaida, H., Sumarti, S., Bignami, C., Griswold, J., Carn, S., Oppenheimer, C., Lavigne, F. (2012). The 2010 explosive eruption of Java's Merapi volcano-a "100-year" event. Journal of Volcanology and Geothermal Research 241: 121-135.

Trolese, M., Giordano, G., Komorowski, J.-C., Jenkins, S., Baxter, P. J., Cholik, N., Raditya, P. \& Corrado, S. (2018) Very rapid cooling of the energetic pyroclastic density currents associated with the 5 November 2010 Merapi eruption (Indonesia). Journal of Volcanology and Geothermal Research 358: 1-12.

Uehara, D., Cas, R.A.F., Folkes, C., Takarada, S., Oda, H., Porreca, M. (2015) Using thermal remanent magnetisation (TRM) to distinguish block and ash flow and debris flow deposits, and to estimate their emplacement temperature: 1991-1995 lava dome eruption at Mt. Unzen volcano, Japan. Journal of Volcanology and Geothermal Research 303: 92-111. DOI: https://doi.org/10.1016/j.jvolgeores.2015.07.019.

Voight, B., Davis, M.J. (2000) Emplacement temperatures of the November 22, 1994 nuée ardente deposits, Merapi Volcano, Java. Journal of Volcanology and Geothermal Research 100: 371-377. https://doi.org/10.1016/S0377-0273(00)00146-3.

Walker, G.P.L. (1971) Grain-size characteristics of pyroclastic deposits. Journal of Geology 79: 696-714. 